\title{
THE EFFECT OF STORE ENVIRONMENT, AVAILABILITY OF MONEY AND TIME, HEDONIC CONSUMPTION TENDENCY ON EMOTIONAL STATES AND ITS IMPACT ON IMPULSE BUYING BEHAVIOUR
}

\author{
Octaprinanta Nandha*, Kusumawati Andriani, Pangestuti Edriana \\ Faculty of Administrative Science, University of Brawijaya, Indonesia \\ *E-mail: thatha7474@gmail.com
}

\begin{abstract}
The objective of this study is to analyze and explain the effect of some situational factors toward emotional states and impulse buying behaviour. This research is explanatory research. The sampling technique is simple random sampling. Populations in this study is the visitor at Loka Supermarket Malang City Point. The sample of this study was 119 respondents. The data were analyzed using Path Analysis. The findings of this study show Store Environment and Availability of Money had a significant effect towards Emotional States, while Availability of Time and Hedonic Consumption Tendency had not a significant effect towards Emotional States. Furthermore, Store Environment, Availability of Money, Hedonic Consumption Tendency had a significant effect towards Impulse Buying Behaviour. However, Availability of Time had not a significant effect towards Impulse Buying Behaviour. And the last result show Emotional States had a significant effect towards Impulse Buying Behaviour.
\end{abstract}

\section{KEY WORDS}

Store environment, availability of money, availability of time, hedonic consumption tendency, emotional states, impulse buying behavior.

The rapid development of modern retail presents two significant impacts for consumers and certainly retail company itself. Consumers benefit with more choices in meeting their daily needs, while at the retail company becomes a challenge to survive and continue to compete with other retail establishments. Competition occurs as more and more consumer choice in determining the retail companies which are better suited to the tastes and meet the expectations of customers in the shop, so the manager of a retail company needs to have strategies that are more oriented to consumers, produce and deliver products and services in accordance with needs and desires of consumers.

A retail company also needs to understand the factors that can be incentive for consumers to shop primarily impulse buying. The factors include store environment (store atmosphere, store design, employee assistance), availability of money and time, hedonic consumption tendency, which can be influenced by the emotional state of consumers as well as an incentive for consumers to shop even impulse buying. Graa and elKebir (2012) stated that one of the factors driving consumer make purchases is deciding environmental conditions store (store environment). Store well-managed environment is a reason of customers feel comfortable and finally shopping with pleasure.

Other findings known to the availability of money and time has a significant influence in inducing a decision for the consumer in the shop (Foroughi, 2012). The phenomenon of impulse buying is also related to the hedonic consumption tendency, where consumption trends indicate hedonic aspects of consumer behavior related to various senses, fantasy and emotional aspects of a person to the product (Hirschman and Holbrook, 1982). Further, the condition of consumer emotions can be an important variable in realized an impulse buying behavior. This is supported by research conducted by Hausman (2000) who concluded emotions strongly influence the action or decision of a shop outside of the previous plan.

The tendency of impulse buying is the purchasing behavior trends emerging in hypermarkets and supermarkets (Bayley and Nancarrow, 1998). This phenomenon is pushing the company to effective marketing strategy with research of consumer behavior by 
using a factor of impulse buying. Retail development has become a trend of its own in developing the economy in Indonesia, one of which carries the concept of modern retail Lifestyle Supermarket is LOKA. The concept was chosen taking into consideration market segmentation to target consumers LOKA, namely the upper middle segment.

LOKA as supermarket lifestyle brands carrying the slogan 'Engage, Experience, Every Day' to express the concept in presenting the shopping experience pleasant and familiar, every day. The use of the trolley to shop was given a unique touch by using a variety of colors and bright, so that visitors can choose their favorite color. LOKA provides a variety of daily necessities ranging from food, clothing, household furniture to electronic appliances. Design Loka Malang City Point prioritizes convenience in shopping for consumers, which in turn stimulate the consumer to make a purchase.

Based on these descriptions, the purpose of this study was to test the effect of store environment, availability of money and time, hedonic consumption tendency towards impulse buying behavior by using emotional states as mediation.

\section{LITERATURE REVIEW}

Store Environment. The physical environment of a store affects consumer perception through sensor mechanism of sight, hearing, smell and even touch (Mowen and Minor, 2002). Thus, the main store environment has an important role in creating a feeling or urge to shop at a store. Engel et al., (2008) stated that store environment consists of several elements: the spatial store, aisle space, placement and shape of props, colors, lighting, music, scents and temperature. Further discussion regarding the following elements:

1. Store Atmosphere. The atmosphere of the shop is a more general term than the spatial store and relate to how managers can manipulate the design of buildings, interior space, spatial halls, the texture of the carpet and walls, smells, colors, shapes, and sounds experienced by customers for achieve a certain effect (Mowen and Minor, 2002).

2. Store design. It aims to create an image store which can be remembered and felt by the patrons of a store. Dunne and Lusch (2008) stated store design is divided into four parts that are interrelated that is interior design; exterior design; lighting in the store; scents and sounds in the store.

3. Employee Assistances. An employee of a store is a thing that can not be separated from the defining element of the success of a store reaches its destination. Engel et al., (2008) stated that the store employees so has a very important role. The existence of the store employees can influence consumer purchasing decisions and consumer emotions with some elements, both through the number of people, the hospitality in greeting and other expertise (Liaw, 2007).

Availability of Money. This factor can be understood as the capabilities of a consumer in terms of financial resources. Consumer's decision with regard to a product or brand is strongly influenced by the amount of economic resources (income and wealth) owned, so the consumer is required to be money (Engel et al., 2008). The availability of money that consumers have had a positive influence on a purchase decision and tends to affect mood (mood) someone at the same time and can be defined as the amount of the budget or the extra funds that the individual feels to be used when shopping or on the next day (Beatty and Ferrell, 1998).

Availability of Time. It is the capabilities of a consumer who is related to the amount of time. Time becomes an increasingly important variable in understanding consumer behavior related to how people use the time (Engel et al., 2008). Beatty and Smith (1998) stated the availability of time while shopping also affect the timing and consumers the opportunity to search for products in the shop so that they may lead to impulse purchases.

According to Park et al. (1989), the availability of time refers to consumer perception of time it takes to shop, compared to the available time and influence the purchase decision.

Hedonic Consumption Tendency. Hedonic is a term that refers to the effort to obtain pleasure through the senses (Mowen and Minor, 2002). Hedonic motives related to the need 
for new things, social interaction and leisure (Hausman, 2000). Vazifehdoost (2014) stated that Hedonic Consumption Tendency focuses on the behavioral aspects related to feelings in the plural, imagination and emotion driven to consume a product that is affected by satisfaction and enjoy the benefits of having a product.

Emotional States. Emotion is a strong feeling, and relatively uncontrolled affect our behavior (Hawkins et al., 2000). Emotions can also be regarded as one of the driving someone to act, because uncontrolled feelings cause a reaction or action. Solomon (2007) suggested that a person's mood or emotional or psychological condition at the time of purchase can have a major impact on what he bought or how he assesses his purchase. Mood or emotions a person can be influenced by the design of the store, the weather, or a factor that is considered sensitive for consumers. So, emotion is one of the important aspects that need to be considered in influencing consumers or potential consumers because it may encourage consumers to buy uncontrollably.

Impulse Buying Behaviour. Impulse buying is defined purchases are unplanned, accidental, immediately and without purpose beforehand (Cobb and Hoyer, 1986). Engel et al., (2008) defined impulse buying is buying that occurs when consumers experience the feeling of a sudden, powerful and strong urge to buy something immediately. Impulse buying behavior has four types, namely pure impulse, suggestion impulse, planned impulse and impulse reminder.

\section{METHODS OF RESEARCH}

The study used a quantitative research methods since the purpose is to explain the correlation among variables store environment, availability of money, availability of time dan hedonic consumption tendency on emotional states and impulse buying behaviour. This research can be categorized as a causality research. The method that is used to explain the causal relationships among variables is the survey method. The location of this research at LOKA Supermarket Malang City Point in Malang. The sampling technique used was Simple Random Sampling.

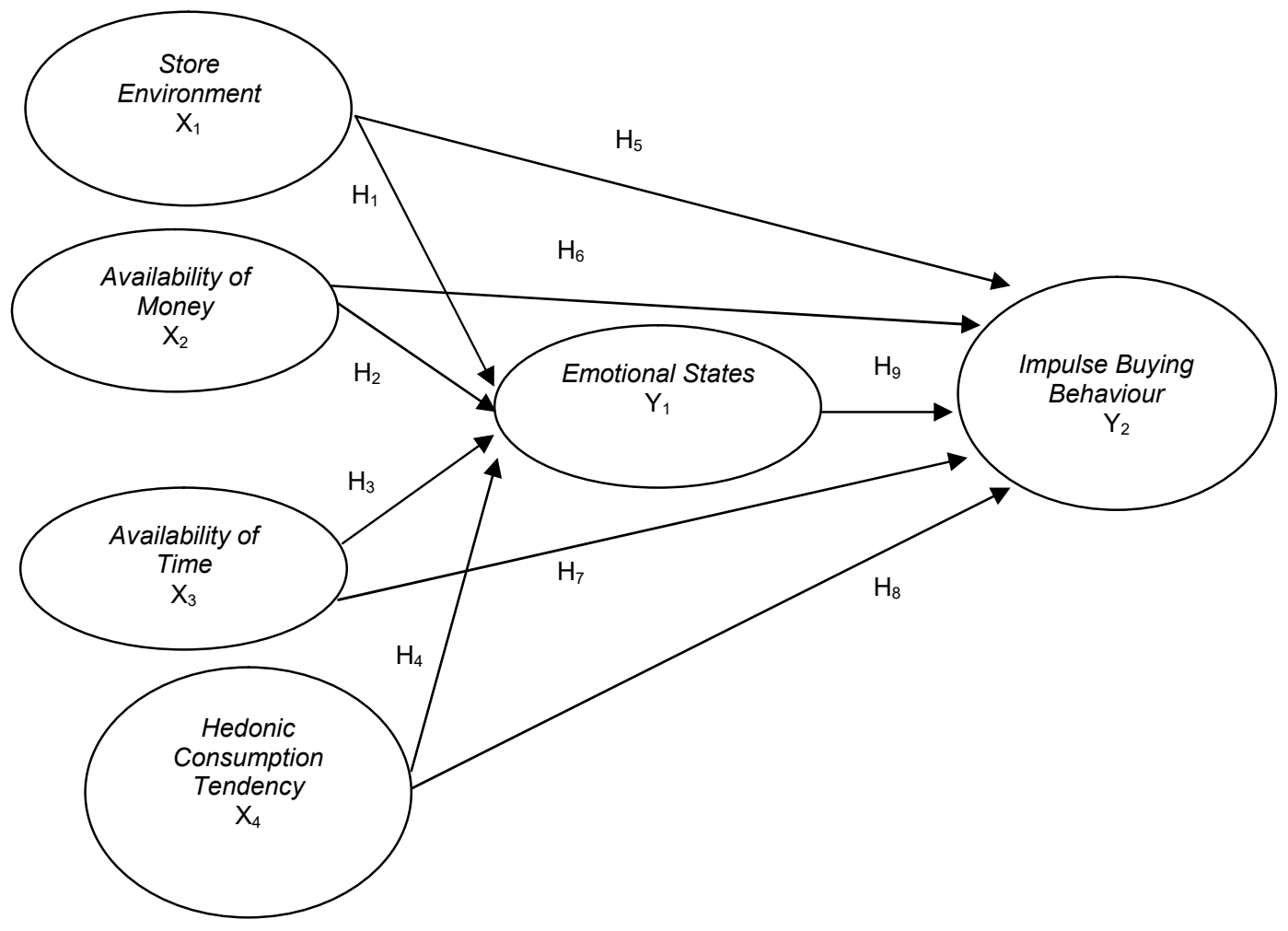

Figure 1 - Research Framework 
The samples was 119 respondents. This study used a questionnaire distributed to consumers on LOKA Supermarket Malang City Point. Furthermore, the method of data analysis in this research is descriptive data analysis, which has a goal to show the data image collected from the research locations. The analysis technique that is used is the path analysis with SPSS applications. The research framework is presented in Figure 1.

Hypothesis:

- $\mathrm{H}_{1}$ : Store Environment had a significant influence on Emotional States;

- $\mathrm{H}_{2}$ : Availability of Money had a significant influence on Emotional States;

- $\mathrm{H}_{3}$ : Availability of Time had a significant influence on Emotional States;

- $\mathrm{H}_{4}$ : Hedonic Consumption Tendency had a significant influence on Emotional States;

- $\mathrm{H}_{5}$ : Store Environment had a significant influence on Impulse Buying Behaviour;

- $\mathrm{H}_{6}$ : Availability of Money had a significant influence on Impulse Buying Behaviour;

- $\mathrm{H}_{7}$ : Availability of Time had a significant influence on Impulse Buying Behaviour;

- $\mathrm{H}_{8}$ : Hedonic Consumption Tendency had a significant influence on Impulse Buying Behaviour;

- $\mathrm{H}_{9}$ : Emotional States had a significant influence on Impulse Buying Behaviour.

\section{RESULTS AND DISCUSSION}

Profiles of the respondents. $40.3 \%$ of the respondents were male while the remaining $59.7 \%$ of them were female. $39.5 \%$ of the respondents were between 22 and 26 years old, $26.9 \%$ was between 27 and 31 years old, $16.0 \%$ was between 32 and 36 years old, $8.4 \%$ was between 37 and 41 years old and $3.4 \%$ was between 42 and 46 year old. In terms of level of education, $0.8 \%$ of them were junior high school graduate, $14.3 \%$ was senior high school graduate, $16.8 \%$ had diploma program, $62,2 \%$ of the respondents were university students, $5.9 \%$ had the master's degree, $7.6 \%$ was government officers, $49.6 \%$ worked in private institutions, $1.7 \%$ was police officers and $0.8 \%$ was worked in the army, $5.81 \%$ owned business, $13.2 \%$ of the respondents had other occupation. $16.0 \%$ of the respondent had an income of less than two million, $77.3 \%$ had an income between two million and five million, 6 , $7 \%$ had an income of more than five million rupiah.

Construct validity and reliability. Based on the analysis, the loading factors of all of the indicators that measured the 6 variables (store environment, availability of money, availability of time, hedonic consumption tendency, emotional states and impulse buying behaviour) were higher than 0.6. Thus, all of the indicators were valid. The calculation of the path coefficient is processed using SPSS version 17.0 for Windows. Path analysis is used to analyze the patterns of relationships between variables in order to determine the effect of directly or indirectly, exogenous and endogenous. The test result in substructures 1 (Table 1) shows that two variable that store environment and availability of money has significance on emotional states, and two other variables, namely availability of time and hedonic consumption tendency has no significance on emotional states.

Table 1 - Substructure Output Part 1

\begin{tabular}{|l|l|l|l|}
\hline The Effect & \multicolumn{1}{|c|}{ Path Coefficient } & \multicolumn{1}{c|}{ Significances } & \multicolumn{1}{c|}{ Information } \\
\hline $\mathrm{X}_{1} \mathrm{Y}_{1} \longrightarrow$ & 0,607 & 0,000 & Significant \\
\hline $\mathrm{X}_{2} \mathrm{Y}_{1} \longrightarrow$ & 0,248 & 0,002 & Significant \\
\hline $\mathrm{X}_{3} \mathrm{Y}_{1} \longrightarrow$ & $-0,027$ & 0,718 & No Significant \\
\hline $\mathrm{X}_{4} \mathrm{Y}_{1} \longrightarrow$ & $-0,057$ & 0,490 & No Significant \\
\hline
\end{tabular}

Information: The effect of Store Environment $\left(X_{1}\right)$, Availabilty of Money $\left(X_{2}\right)$, Availability of Time $\left(X_{3}\right)$, Hedonic Consumption Tendency $\left(X_{4}\right)$ on Emotional States $\left(Y_{1}\right)$.

The test result in substructures 2 (Table 2) shows that the path coefficient variable Store Environment $\left(X_{1}\right)$ of 0.453 with a significance value of 0.000 , Availability of Money $\left(X_{2}\right)$ of 0.230 with a significance value of 0.008 , Availability of Money $\left(X_{3}\right)$ of -0.201 with a significance value of 0.007 , Hedonic Consumption Tendency $\left(X_{4}\right)$ of 0.193 with a significance value of 0.020 , Emotional States $\left(Y_{1}\right)$ of 0.293 with significance value of 0.002 , then all of exogenous variable has a significant influence on endogenous variable, namely Impulse 
Buying Behaviour $\left(Y_{2}\right)$. The test results prove that the variable Store Environment $\left(X_{1}\right)$, Availabilty of Money $\left(X_{2}\right)$, Availability of Time $\left(X_{3}\right)$, Hedonic Consumption Tendency $\left(X_{4}\right)$ directly influence the variable Impulse Buying Behaviour $\left(\mathrm{Y}_{2}\right)$ and indirectly influences with the mediation variable Emotional States $\left(\mathrm{Y}_{1}\right)$.

Table 2 - Substructure Output Part 2

\begin{tabular}{|l|l|l|l|}
\hline The Effect & \multicolumn{1}{|c|}{ Path Coefficient } & \multicolumn{1}{c|}{ Significances } & \multicolumn{1}{c|}{ Information } \\
\hline $\mathrm{X}_{1} \mathrm{Y}_{2} \longrightarrow$ & 0,453 & 0,000 & Significant \\
\hline $\mathrm{X}_{2} \mathrm{Y}_{2} \longrightarrow$ & 0,230 & 0,008 & Significant \\
\hline $\mathrm{X}_{3} \mathrm{Y}_{2} \longrightarrow$ & $-0,201$ & 0,007 & Significant \\
\hline $\mathrm{X}_{4} \mathrm{Y}_{2} \longrightarrow$ & 0,193 & 0,020 & Significant \\
\hline $\mathrm{Y}_{1} \mathrm{Y}_{2} \longrightarrow$ & 0,293 & 0,002 & Significant \\
\hline
\end{tabular}

Information: The effect of Store Environment $\left(X_{1}\right)$, Availabilty of Money $\left(X_{2}\right)$, Availability of Time $\left(X_{3}\right)$, Hedonic Consumption Tendency $\left(X_{4}\right)$, Emotional States $\left(Y_{1}\right)$ on Impulse Buying Behaviour $\left(Y_{2}\right)$.

The effect of Store Environment on Emotional States. In accordance with the result of the study, Store Environment has a significant effect on Emotional States. Table 1 showed the path coefficient by 0,607 . The result of this study reinforces previous research, such as the research of Graa and Dani-elKebir (2013). They found that store environment has a positive significant on emotional states. Store environment designed good have to create a mood or feeling while doing shopping activity (Peter and Olson, 1999). This result showed hypotheses 1 were accepted.

The effect of Availability of Money on Emotional States. In accordance with the result of the study, Availability of Money has a significant effect on Emotional States. Table 1 showed the path coefficient by 0,248 . The result of this study reinforces previous research, such as the research of Foroughi (2012). They found that availability of money has a positive significant on emotional states. Money is the amount paid by consumers to obtain products or services, where the availability of money to have a linear relationship with positive emotions (Peter and Olson, 1999). This result showed hypotheses 2 were accepted.

The effect of Availability of Time on Emotional States. In accordance with the result of the study, Availability of Time has a no significant effect on Emotional States. Table 1 showed the path coefficient by -0.027 . The result of this study is different from previous research, such as the research of Foroughi (2012). They found that availability of time has a significant influence on emotional states, but this study showed availability of time has a no significant influence and negative on emotional states. The results are the new findings related to results of a general overview of respondents who showed most respondents are groups of workers (private sector employees) who have a tendency to shop for a short time and have the pressure within shopping at Supermarket Loka Malang City Point. This result showed hypotheses 3 were rejected.

The effect of Hedonic Consumption Tendency on Emotional States. In accordance with the result of the study, Hedonic Consumption Tendency has a no significant effect on Emotional States. Table 1 showed the path coefficient by -0.057 with significance value of 0.490 . The result of this study is different from previous research, such as the research of Pattipelohy (2013). They found that availability of time has a significant influence on emotional states, but this study showed availability of time has a no significant influence and negative on emotional states. This result showed hypotheses 4 were rejected.

The effect of Store Environment on Impulse Buying Behaviour. In accordance with the result of the study, Store Environment has a significant effect on Impulse Buying Behaviour. Table 1 showed the path coefficient by 0,453 . The result of this study reinforces previous research, such as the research of Graa and Dani-elKebir (2013). They found that store environment has a positive significant on impulse buying behavior with moderated by emotional state of consumers. This result of this research was supported opinion of experts that a comfortable feeling when shopping at a department store that has the environmental conditions that favor increasing their store purchases is not planned. This result showed hypotheses 5 were accepted. 
The effect of Availability of Money on Impulse Buying Behaviour. In accordance with the result of the study, Availability of Money has a significant effect on Impulse Buying Behaviour. Table 1 showed the path coefficient by 0,230 . The result of this study reinforces previous research, such as the research of Pattipelohy (2013). They found that availability of money has a positive significant on impulse buying behaviour. Further, Beatty and Ferrell (1998) stated that the availability of the funds have an important role, primarily as a facilitator whereby the guaranteed availability of funds, the more encouraged Impulse Buying. This result showed hypotheses 6 were accepted.

The effect of Availability of Time on Impulse Buying Behaviour. In accordance with the result of the study, Availability of Time has a significant effect on Impulse Buying Behaviour. Table 1 showed the path coefficient by $-0,201$. The result of this study is different from previous research, such as the research of Pattipelohy (2013). They found that availability of time has a positive significant on impulse buying behavior, but this result showed that availability of time has a negative effect on impulse buying behaviour. Furthermore, it is known from the intensity of visits to the Loka Supermarket Malang City Point majority only once a month, this shows that most respondents do not have much time to shop. This result showed hypotheses 7 were accepted.

The effect of Hedonic Consumption Tendency on Impulse Buying Behaviour. In accordance with the result of the study, hedonic Consumption Tendency has a significant effect on Impulse Buying Behaviour. Table 1 showed the path coefficient by 0, 193. The result of this study reinforces previous research, such as the research of Vazifehdoost (2014). They found that hedonic consumption tendency has a positive significant on impulse buying behaviour. This result showed hypotheses 8 were accepted.

The effect of Emotional States on Impulse Buying Behaviour. In accordance with the result of the study, Emotional States has a significant effect on Impulse Buying Behaviour. Table 1 showed the path coefficient by 0,293 . The result of this study reinforces previous research, such as the research of Graa and Dani-elKebir (2013). They found that an emotional state has a positive significant on impulse buying behaviour. Further, Hawkins et al., (2000) suggested the emotion is said to be one of the driving someone to act, because uncontrolled feelings cause a reaction or action, in this case the reaction or action may be unplanned purchasing decisions. This result showed hypotheses 9 were accepted.

\section{CONCLUSION}

The main objective of the study is to describe the influence of store environment, availability of money, availability of time, hedonic consumption tendency towards emotional states and its effect on impulse buying behavior. Based on the findings, there are direct and indirect correlation between variables. The first finding is store environment and availability of money has influenced towards emotional states. Second, availability of time and hedonic consumption tendency does not have any significant influence towards emoional states. Third, store environment, availability of money, availability of time, hedonic consumption tendency and emotional states has significant influence towards impulse buying behavioral. Fourth, emotional states has a role as a mediator in the correlation between the store environment, availability of money, availability of time, hedonic consumption tendency and impulse buying behavioral or store environment, availability of money, availability of time, hedonic consumption tendency has indirect relationship towards impulse buying behaviour.

Research limitation. This research is still there are limitations that can be enhanced by further research in the future. First, this study discusses the concept of Impulse Buying Behavior that occurs in Loka Supermarket Malang City Point with some of the factors that influence it. Impulse Buying concepts that are new require more effort to explain to the respondents, but with limited time owned by investigators led to the approach taken to the respondent cannot be done thoroughly. Second, characteristics of respondents were selected in this study showed a homogenous tendency, where the majority of respondents are workers (Private Employees). This led to obtaining the results of consumer behavior in their purchasing decisions more focused on the same tendency. 


\section{REFERENCES}

1. Bayley, G and Nancarrow, C. 1998. "Impulse Purchasing: A Qualitative Exploration of the Phenomenon", Qualitative Market Research: An International Journal, Vol. 1, No. 2.

2. Beatty, S. E. and M. Elizabeth Ferrell. 1998. "Impulse Buying: Modeling Its Precursors", Journal of Retailing, Vol. 74, No. 2.

3. Beatty, S. E., and Smith, S. M. 1987. External Search Effort: An Investigation Across Several Product Categories. Journal of Consumer Research, Vol. 14, No. 1.

4. Cobb, C.J and Hoyer, W.D. 1986. "A Planned Versus Impulse Purchase Behaviour", Journal of Retailing. Vol. 62, No. 6.

5. Dunne, P.M and Lusch, R.F. 2005. Retailing (5th Ed.). Ohio: South Western, A Division of Thompson Learning

6. Engel, J., Roger D. Blackwell dan Paul W. Miniard. 2008. Perilaku Konsumen. Alih bahasa: Budyanto. Jilid I. Jakarta: Binarupa Aksara Publisher

7. Foroughi, Amir. 2012. "Exploring the Influence of Situational factors (Money and Time Available) on Impulse Buying Behaviour among different Ethics", Marketing Management Journal, Vol. 46, No. 20.

8. Graa, Amel and Dani-elKebir, Maachou. 2012. "Application of Stimulus and Response Model To Impulse Buying Behaviour of Algerian Consumers", Serbian Journal of Management, Vol. 7, No. 1.

9. Hausman, Angela. 2000. "A Multi Method Investigation of consumer motivations in impulse buying behavior", Journal of Consumer Marketing Vol. 17, No. 5.

10. Hawkins, Dell., Roger J. Best and Kenneth A. Coney. 2000. Consumer Behaviour: Building Marketing Strategy. New York: McGraw-Hill

11. Hirschman, E. C. \& Holbrook, M. B. 1982 "Hedonic consumption: emerging concepts, methods and propositions", Journal of Marketing, Vol. 46, No. 3.

12. Liaw, Gou-fang. 2007. "The Influence of Multiple Store Environment Cues On Shopping Mood and Patronage Satisfaction", Journal of Retailing and Consumer Services, No. 11

13. Mowen, John C. dan Michael Minor. 2002. Perilaku Konsumen. Alih Bahasa: Dwi Kartini Yahya. Jilid 2. Jakarta: Penerbit Erlangga

14. Park, C., Whan, Iyer., Easawar, S and Smith Daniel, C. 1989. "The Effect of Situational Factors on in-Store Grocery Shopping Behaviour: The Role of Store Environment and Time Available for Shopping. Journal of Consumer Research, Vol. 15

15. Pattipeilohy, Victor Ringhard. 2013. The Influence of the Availability of Money and Time, Fashion Involvement, Hedonic Consumption Tendency and Positive Emotion towards Impulse Buying Behavior in Ambon City. Tesis Universitas Brawijaya Malang

16. Solomon, R. Michael. 2007. Consumer Behavior, Buying, Having, and Being. 8th Edition. New Jersey: Prentice Hall.

17. Vazifehdoost, Hossein. 2014. "Evaluation of the Influence Fashion Involvement, Personality Characteristics, Tendency to Hedonic Consumption and Store Environment on Fashion-Oriented Impulse Buying", Mediteranian Journal of Social Sciences. Vol. 5, No. 16. 